Cahiers
de a Recherche
surles Droits

Cahiers de la recherche sur les droits fondamentaux

$6 \mid 2008$

Pouvoirs exceptionnels et droits fondamentaux

\title{
La portée de l'article 3 de la Convention européenne des droits de l'homme, Catherine-Amélie Chassin (dir.)
}

\section{(2) OpenEdition}

Journals

Édition électronique

URL : https://journals.openedition.org/crdf/6957

DOI : $10.4000 /$ crdf.6957

ISSN : 2264-1246

Éditeur

Presses universitaires de Caen

Édition imprimée

Date de publication : 31 décembre 2008

Pagination : 188

ISBN : 978-2-84133-259-5

ISSN : $1634-8842$

Référence électronique

"La portée de l'article 3 de la Convention européenne des droits de l'homme, Catherine-Amélie Chassin

(dir.) », Cahiers de la recherche sur les droits fondamentaux [En ligne], 6 | 2008, mis en ligne le 11

décembre 2020, consulté le 15 novembre 2022. URL : http://journals.openedition.org/crdf/6957 ; DOI : https://doi.org/10.4000/crdf.6957 


\section{La portée de l'article 3 de la Convention européenne des droits de l'homme}

Catherine-Amélie Chassin (dir.)

Bruxelles, Bruylant (Rencontres européennes ; 5), 2006

ISBN : 2-8027-2246-8; 300 p. ; $60 €$

L'article 3 de la Convention européenne des droits de l'homme prohibant la torture et les traitements et peines inhumains et dégradants est un texte majeur, souvent analysé mais dont la portée exacte n'est pas toujours nettement définie. Les présents travaux visaient tout à la fois à clarifier l'objet de l'article 3 et sa portée concrète dans l'ordonnancement juridique.

Sur le plan interne, son utilisation par le juge administratif et le juge judiciaire reste limitée. Ce phénomène est d'autant plus regrettable que l'interdiction de l'article 3 a pu être qualifiée d'absolue - par la Cour européenne, ou le Tribunal pénal pour l'exYougoslavie - et que l'on retrouve son pendant dans la Convention interaméricaine des droits de l'homme - la Charte africaine des droits de l'homme et des peuples ne bénéficiant pas, à ce jour, d'une protection juridictionnelle internationale effective. La Cour de Strasbourg a elle-même développé une jurisprudence riche; elle a notamment intégré dans le champ protecteur de la Convention des catégories de personnes spécifiques (détenus et étrangers), mais elle a pu également développer une protection particulière pour les malades et les mineurs. Son application récente dans certains cas douloureux, comme celui des disparitions forcées, est bien réelle. La Cour européenne a en outre développé deux facettes de cet article 3 : à l'obligation substantielle posée par le texte lui-même - que ce soit dans son aspect vertical ou horizontal - elle a ajouté des obligations procédurales, notamment une obligation d'enquête effective à la charge de l'État mis en cause. 